Henri Oripeloye

Henri Oripeloye is associated with the Department of English, Obafemi Awolowo University, Ile-Ife, Nigeria.

Email: oripeloyehenri@gmail.com

\author{
Factional realities in Remi Raii's \\ Gather My Blood Rivers of Song
}

\title{
Factional realities in Remi Raji's Gather My Blood Rivers of Song
}

This paper explores the transformative vision of the Nigerian poet, Remi Raji from imaginative mooring in his earlier works to factional realities in Gather My Blood Rivers of Song published in 2009. In some poems in this collection, Raji embraces factional realities as he grapples with the narration of actual existence in Nigeria. This signifies a movement away from the speculative construct of the imagination as he presents the tangible properties of events, not as history, but the facts in reality. This differentiates him from other writers who merely re-echo or document events. Based on the materialist frame of reference presented in some of the poems in this collection, Raji is able to enact plausible narrations that have identifiable referentiality through which he guides his poetic presentation of actual human existence. Keywords: factional realism, imagination, Nigerian poetry, Remi Raii, representative constructs.

\section{Introduction}

Remi Raji is one of the most outstanding voices among the third generation poets in Nigeria whose main poetic concern is the agony of existence occasioned by the malfeasant regimes in this part of the world. He is a poet whose writings reflect the social, political and cultural disruption of his society. He has published five collections of poetry which include: Gather My Blood Rivers of Song (2009), A Harvest of Laughters (1997), Webs of Remembrance (2001), Shuttlesongs: America-A Poetic Guided Tour (2003), and Lovesong for My Wasteland (2005). His poetry has won many awards such as the Association of Nigerian Authors/Cadbury Poetry Prize in 1997 and the Association of West African Young Writers Award in 1997. Remi Raji is a social, cultural and politically conscious poet who exposes and ridicules the inanities orchestrated by the political dictators in African countries. He does not only condemn the leaders; his poetry is quite didactic as it shows the path to progress through collective action in the search for an egalitarian society [which is] devoid of injustice and oppression. This he has been doing through the tropes of parody, vitriolic laughter and acerbic criticism. What I propose in this paper is a critical apprehension of the factional realist intent in Remi Raji's Gather My Blood Rivers of Song. Factional narrative involves the transformation of physical events to literature; this transformation is presented as it exists, not as a representation or a construct, but a tangible expression of actuality. Factional reality signifies a movement away from the speculative construct common 
in imaginative realism; it presents the tangible properties of events, not as history, but as facts in its reality. Four poems in Gather My Blood Rivers of Song, namely: "The coffin carpenter of Campbell Street", "I know the secrets of open roads", "Song of Toronto" and "Somewhere, she shall be stoned to death" will be used to contextualize this proposition.

\section{Theoretical framework}

Realism as a body of knowledge has attracted scholars' interest from the time of Plato and Aristotle up till the present moment, but no one has been able to provide an all-embracing or accepted answer to the problematic nature of this concept. As a theoretical field, realism is no doubt one of the intricate discourses in literary studies as every literature strives to achieve one form of realism or the other. Part of this problem is the open-endedness and the vagueness that this concept has attracted among scholars. As a literary language, realism is difficult to define because it is a term that is open to contestations. Pam Morris (2) sees it as a "term that is frequently invoked in making fundamental ethical and political claims or priorities, based upon perception of what is 'true' or 'real'. As such, the usage is often contentious and polemical". Despite these controversies, realism has become the particular and specific social situations that reveal the actual engagement of textual representation as the material evidence of the social world. The realist intention of writers has always been taken for granted in the reading of literature because there is the tendency to figure out some of the values or ideas expressed in a text as correlating with events in the real world. Biodun Jeyifo (3) shares this position when he says that the realist believes "that language and literature can be made to truthfully and providentially reflect the world in which we live". The contestation with this view is on the word "reflect" which conveys a transmissional meaning outside reality. Also, Chinua Achebe (99) in "The truth of fiction" makes a case for the inevitability of imagination in human society when he claims that

[g]iven our questioning nature the end of which is discovery, and given our existential limitations especially the vastness of our ignorance, one can begin to appreciate the immeasurable blessings that our imagination could confer on us. [...] Our imagination can narrow the existential gap by giving us in a wide range of human situations the closest approximation to experience that we are ever likely to get....

In spite of the place and importance accorded imagination by Achebe, what comes out of this effort shows the lacuna in imaginative reasoning as it only produces the "closest approximation to experience".

It is assumed that a writer must project the aspirations of the society but the manner of this presentation is determined by the common assumption that the writer faithfully reflects commonplace things in the society; this tendency stands the risk 
of perspectival distortions as the writer relies solely on his imaginative power. Quite often, writers provide fantastic, improbable and incredible situations as real but what has been presented if properly scrutinized cannot pass the test of truth value as they lack the grains of circumstantial evidence. In the pursuit of coherent intelligibility, the writer maps out the travails and privations of his society through auxiliary constructions and one may take these assessments as faithful recollection of an epoch in literature. It is on account of this that Louise Rosenblatt (190) provides an insight into the fallibility of imaginative reading in real life situation when she claims that

in imagination we rehearse various possibilities of action in a given situation. We go through a process of imaginative trial and error, trying out different modes of behaviour and working out their probable effects. When the situation arises in actual life, we are better prepared to act successfully. [. . . ] Literature may thus offer us a means of carrying on some of the trial-and-error experimentation that might be disastrous in real life.

Literature in its imaginative propensities projects the aspirations of a writer on what a society should be. In this assignment, the writer assumes the duties of a prophet or, to be pejorative, that of a gambler since it is not in all cases that a prophet has been proved accurate in his predictions. Warren and Wellek (95) admit that "a writer inevitably expresses his experience and total conception of life; but it would be manifestly untrue to say that he expresses the whole life [...] completely and exhaustively". As readers, we have the predilection towards interpreting a text as a realist art when we are familiar with the events so narrated. For instance, Achebe has been praised for his realist mode of telling in Things Fall Apart (1958). But this novel is not realistic in the real sense of the term; what creates the pretentious or pseudo-realism in the text is that the author narrates "our" slice of the story. The characters and events are not concrete labels; at best they are representative constructs which may create outlandish representation of a real phenomenon. But ironically, as consumers of literary narrations, we rely on the ideological bent instead of the concrete facts in our search for the realist inclination of the writers. This is more so because the " $\mathrm{I}$ " of the narrator as entrapment is suggestive of witnessing but if we unpack the narratives in the text, it becomes clearer that the text is not self-reflexive but mere fanciful conjecture that reveals the consciousness of values, far from the physical manifestation of reality. In most cases, writers imbued their fantastic, improbable and incredible conditions with "padded" realities which are mere permutations or resemblance of reality. Wellek and Warren (213) have substantiated this claim by saying that "the reality of a work, i.e. its illusion of reality, its effects on the reader as a convincing reading of life, is not necessarily or primarily a reality of circumstance or detail or commonplace routine". Neil Lazarus, writing about naturalism, a concept that has much in common with realism, opines that naturalism only projects the surface ideas at the expense of deep meaning of everyday life. He thus dismisses the ideological 
posturing of naturalism because "in representing the blunt facts of social life, the naturalists lost sight of the social meaning of these facts. Their failure, accordingly, was a failure to render society in its totality, as a contradictory unity" (Lazarus 341). This same tendency is also associated with imaginative realism whose main tenet is the presentation of an unbiased and accurate depiction of the society (Todd). The fact that these representations depend on the imagination leaves much in doubt in terms of its accuracy or truth value.

Abiola Irele in The African Imagination, having foreclosed the relevance of the Romantic imagination in the interpretation of African literature in contemporary time, underscores the development of a movement he describes as "the new realism" to account for the methods adopted by contemporary African writers to project the sociopolitical realities in Africa. This new way of representing reality, according to Irele (214), "relates essentially to a new attitude toward the African experience in the more recent literature, a new apprehension of events, social forces, and human character as they interact to create the sense of a moral universe impinging upon the writer's consciousness". The focus on reality that is underscored by Irele is on the so-called imaginative realism that borders on the formal presentation of experience. This tends to promote "intentional fallacy" as the writer strives to project possibilities that are generated through human interactions. In the context of this paper, realism as a theoretical approach enables us to observe the correspondences and analogies in Gather My Blood Rivers of Song to establish the factual narration inherent in this collection.

\section{Review of literature}

Many of the critical works on Remi Raji's poetry (Egya, "The nationalist imagination in Remi Raji's Lovesong for my Wasteland", Poetics of Rage: A Reading of Remi Raji's Poetry; and Oha, "The rhetoric of cross-cultural engagement and tropology of memory in Remi Raji's travel poetry") explore his concern for socio-cultural, political and economic stability in Africa. Sule Egya in "The nationalist imagination in Remi Raji's Lovesong for My Wasteland" looks at the import of nationalism in this work. His major argument dwells on the poet's patriotic zeal which informs his use of poetry to expose the leadership failures and plunder of yesterday and today, and presenting a hope that is predicated on the people's collective stand to build their ravaged land. In his earlier collections, Remi Raji captures as imaginatively real as possible the African predicament. But his valorization of the oppressive tendencies is merely documented; it lacks the starkness that is necessary to communicate factional realities. These collections-A Harvest of Laughters, Webs of Remembrance and Lovesong for My Wasteland - to a larger extent document the problems within the Nigerian nation at a particular point in time but these issues are presented as observed experience and not a lived one; there is no expression of physical existence as the discourse thrives in the realm of "unbounded imagination" (Smajic 8). In his search for a catalyst for 
a change in the society, Raji relies on the resources of imagination to unravel the maladies in the system so that the people can be conscious of this and proffer a solution, if possible. The question that naturally arises from this mode of imaginative presentation is that: is it possible for a writer who relies on imaginative power in the presentation of real existence not to be biased in his analyses? In actual sense, imaginative realism cannot capture the whole essence of life; what it does is to abstract a phenomenon which is then taken as a representative construct. In philosophical reasoning, a universal reality exists but only mentally existent; therefore, "realism is thus opposed to idealism, which holds that no such material objects or external realities exist apart from our knowledge or consciousness of them, the whole universe thus being dependent on the mind or in some sense mental". (Edwards 77)

Remi Raji's poetry is about oppression, nature, love and, essentially, socio-political bastardization. He denounces the vultures and hawks in African political system and uses metaphor and semantic manipulations to satirize and lambast the inanities of these rulers. The naivety, indolence and ineptitude of the populace are also clearly foregrounded; in all, his poetry is a condensation of his thoughts about things around him. From this, we can infer that Raji communicates his personal exegesis on societal expectations to the readers. For instance, in Webs of Remembrance, he paints the picture of a country under the stranglehold of military despots. In his assessment, the country has suffered series of plunder as depicted in "Cyclone III":

Darkness springs

Where the farmer falls

We reap the bounty

Of griefs newly grown

We reap

The spittle in the soil

The salt and the sand

We grieve and reap. (Webs 30)

This appraisal is personal and, therefore, subjective as the poet relies on the elements of fantasy in his presentation, this cannot be a faithful representation of reality but an instinctual response to unpleasant events in the country. Raji (Webs 9) confesses to this claim in his author's note in Webs of Remembrance: "The totality, flesh and spirit, of the poems in this collection is conceived as an instinctive response to the various experience of being dehumanized by the weapons of state in a period of anomie." His voice also dominates the narration in Harvest of Laughters to the extent that he transports the readers to the realm of fantasy in his attempt to wrap the misdeeds of the period in prophetic laughter. According to Sule Egya (Poetics 74)

Raji dwells on laughter as a cushion for his vision and demonstrates that even in the absence of sanity, of love, of hospitality, and of comfort; in the presence of deafening 
chants from the dictator and his acolytes, it is the poet's kind of laughter that the people need to learn to be able to go through the hard times.

Egya's claims in the above quotation are quite presumptuous because in imaginative realism, there is always a playful manipulation of the readers' notion of fact and fiction to the extent that readers unhesitatingly suspend their disbelief. The period enacted by Raji in the poem has been identified by Egya (Poetics) as the regimes of Generals Badamosi Babangida and Sani Abacha but there is no pointer to this direction in the poems except the readers will have to resort to historiographical details. Egya is only reacting as a critic whose duty it is to read meaning into writers' suggestions and locate them as prisms for the exploration of the actuality of existence; hence this judgment is external to the text in question. That imaginative realism does not reveal accurate existence is further accentuated by its ambivalent temporalities in the use of figurative expressions that lead to open-endedness in terms of the making of meaning. This, coupled with the maximum poetic intrusion creates instability in this fictional poetry. In this poem, textual figures-Abacha and Babangida-are misrecognised abstractions of the poet whose transmigration to events in the contexts of the poem is quite vestigial. This conjures a sense of permissible concept in imaginative narration that opens the interpolation of discourses in which a character assumes the figure of another. Therefore, any African despot easily fits into the categories that are associated with these personages. And in this combination of real person and unreal narrative, one encounters doublespeak narratives that create shades of meaning. The avalanche of meanings that readers come out with in such a work essentially depends on their level of appreciation and, therefore, betrays its claim to reality.

\section{Engagement with factional realities}

Faction as opposed to fiction has the capacity to capture events and happenings of an age in a style devoid of symbolic manipulation and magical trajectories with which fictional writers achieve "illusion of reality". In factional narratives, real life occurrences, historiographical details, daily preoccupations and mannerisms involving identifiable personalities become the threshold of narrative balance. Therefore, the events so narrated are commonplace phenomenon that readers can easily identify with as the writer transposes real life experiences into literature without its "defamiliarising antics and characteristics" (Uwasomba 98).

In Gather My Blood Rivers of Song (2009), Raji has moved beyond the mere documentation of experience to inject factional reality into his work. The collection becomes, in the process, not just a symbolic manipulation, but a comprehensive or total narration of actualities. It is on account of this that one can make a claim that Raji's poetry in the words of Neil Lazarus (340) "is an analytical mode, not a documentary one, concerned to portray and merely to report". The poetry does not only infer 
factional reality but demonstrates it and this pushes Raji's poetry beyond imaginative mooring to a significant literary pedestal in contemporary African poetry. What is interesting in Raji's factional realist inclination is his insistent affirmation of the essence of life in a way that absorbs contemporary reality. He is able to accommodate what Lukacs (125) describes as "the slyness of reality" in his poetry. This implies that Raji has been able to present life as it is; not a slice or imaginative representation. His poetry opens the concrete geography of the landscape to unmask the cycle of love, birth and death, war, poverty, imprisonment and religious bigotry prevalent in the society in order to reveal the deleteriousness of Nigerian leaders.

In his pursuit of factional reality, Raji avoids free play of meaning but relies heavily on "transcendental" signifier - a structuralist posturing that is rooted in immediacy of referential evidence-to convey meaning in his poems. This method allows him to evade the reading trap in structuralism where meaning becomes polyvalent and signification within the text undergoes some levels of indeterminacy. In the selected poems, extra-textual references have no place in the meaning making exercise as the poems exist as autotelic texts where meaning is realized on the structural arrangement of words to project reality. Therefore, Schnieder and Soldkoff's (147) view on fictional texts in the following quotation is more applicable to factional narratives:

what is needed for a fictional entity to exist is not just any general existential claim within a story, but some more specific one: the story must contain quasi-reference to an individual entity [that] can be achieved by the use of proper name, a definite description, or some other device that is in non-fictional contexts suitable for the introduction of a particular object into discourse.

Raji in his poems conveys personal experience and communal life as a form of reality. While there is an astounding influence of the imagination in his poetic creativity, he has been able, through his poetic oeuvre, to create a self that is not distanced from the events; thus he presents poetry as lived experience in the selected poems from Gather My Blood Rivers of Song. Many of the poems in this collection are unique in their presentation of reality especially when they point to actual events within the society. Factional reality creates a spatial tendency for specific events in human life as it accurately explores human values.

One of these poems in Gather My Blood River of Song, "The coffin carpenter of Campbell Street", expresses the factional experience of the poet. A grim humour pervades his descriptions of the trade in death at Campbell Street, Lagos. Different types of coffin are displayed for the public to make a choice. The sight of these coffins jerks the poet to the reality of death and he becomes afraid. The trading activities going on in the shops do not aggregate death as a tragedy; instead it becomes a means to an end. What the poet sees in Campbell Street is the value placed on human tragedy. Instead of death to assume the usual mournful occasion, it becomes an opportunity 
for people to make money and the wishes of the proprietors are that death should be a common phenomenon but not their personal tragedy:

He wishes everyday were a mournful morn

But prays an eternity of mirth for his loving tribe (Gather 44).

Raji's articulation of human tragedy and the commonsensical way in which it is perceived, is derived from his textual concretization of his message through the presentation of actualities of existence among the coffin traders at Campbell Street. Campbell Street is real. It is the street off Broad Street at the intersection in front of Bookshop house in Lagos Island, Nigeria. Along the street, there are ubiquitous undertakers. The names of these companies range from MIC, Ramos, Ebony, Omega, BMC to MCC. The sight of the coffins that are displayed with reckless abandon has a way of welcoming visitors to the world of the dead. Paradoxically, the happiness of the shop owners is also presented through concrete imagery that suggests the ways people capitalize on human tragedies. A macabre drama in this poem is the presentation of the coffin traders who are in the habit of calling customers the way fish sellers in the market do; this shows the value that is placed on human life at Campbell Street. Raji does not reflect on these events or merely document them but provides the actual reality so that the readers become part of the materiality of everyday existence in Campbell Street. We see the inner aspirations of the coffin carpenter of Campbell Street in the following lines which are presented in concrete disclosures:

The Coffin Carpenter of Campbell Street

is a kinder man in seasons of death

for two hearses he gives an extra shroud

for three hearses he gives a rosary

and for four and more he rents a crowd

when he sees a mob he thinks in coffins

somebody's tears are trinkets in his morgeful purse. (Gather 44)

Another poem in the collection "I know the secrets of open roads" is essentially about the poor state of roads in Nigeria. The temperament of the poem presents the oddities on the roads in an objective manner. The poet tells us-the readers-what he knows about these roads. This is a physical description of the dilapidated roads where potholes are common sight. Raji who is familiar with all these roads conveys his experience in a sordid manner. His presentation of the tragedies on the road is linked with the way people have become disenchanted with the possibility of improvement in the Nigerian infrastructural systems. The poem is a voice not an echo of events since the poet conveys an actual problem confronting the nation:

I know the secrets of open roads,

the pulse of urchins of the blood 
the gash and the gripe of highway paths

and potholes, I know the secrets of open roads,

where death hawks her passion per penny. (Gather 33)

"Song of Toronto" recalls "a novel but distasteful phenomenon" (Oripeloye 18) in the Nigerian political system where certificate forgery has become a common preoccupation among the Nigerian political class. Many Nigerian politicians are in habit of presenting fake documents, especially degree certificates, from foreign universities to qualify them to contest for elective positions. In spite of the screening conducted on these documents by the police and allied agents of the government, these politicians always get a clean bill to contest. In 1999, one Salihu Buhari who was elected as the Speaker of the House of Representative in Nigeria was accused of presenting fake degree from the University of Toronto. He denied the accusation and even threatened to take The News magazine that reported the story to court. But after some hide and seek game, he was found to have presented fake documents. He was eventually sacked as the Speaker of the House. It is this sordid event that Raji has responded to as a means of transmitting in poetic form the realities in his country. This poem reflects on the Nigerian political class as they mount political power through odious means and this has become a recurring decimal as many more politicians have been discovered to have forged one document or the other to qualify for certain elective position. Raji in this poem which borders on reality lampoons the educational system in Nigeria where there are many behind the screen maladies:

There are no fake degrees in this land

Where cash is the grammar of class

There are no fake degrees, no

Not forgery, but the devil's artistry

[...]

Why did you go so far

to Toronto and such strange lands

when you can fetch double diplomas

and honorary doctor of Kleptosophy

in the nearby private tower behind the bush? (Gather 47)

In this poem, Raji has painted the real image of his society as he tinkers with the absurdist condition that calls for laughter but in actual sense, is a song of lamentation for the loss of moral consciousness and ethical values in Nigeria. The underlying message of the poet is, in the words of Tayo Olafioye (79) to warn "the leadership elite of the nation and also the factory or storehouse of human resources for the good of the nation. They cannot, and must not, afford to be tainted, rancid and prurient lest they collectively infect the polity". 
That Raji relies on realities of existence as inspiration for his poetic composition is also manifested in "Somewhere, she shall be stoned to death....", a poem dedicated to Amina Lawal, a victim of the Sharia law in northern Nigeria. Lawal has been convicted by the Sharia court in Katsina for having a baby outside wedlock, she is to be stoned to death for her crime but the uproar that greets the judgment pitches the people against this Islamic court and there are unanswered questions about the need for such a law in the society. It is the shenanigans and the hypocrisy in the system that Raji berates in this poem while drawing on a historical event in his contemporary society. Amina Lawal thus becomes the signpost for the condemnation of the oddities the female suffers from the metaphysics of religion and an acerbic patriarchal system.

\section{Conclusion}

Remi Raji has moved from imaginative exploration in his earlier works to embrace factional reality in the selected poems from Gather My Blood Rivers of Song where he presents lived experiences of his people. This claim is anchored in the specificity of textual characters, events and places that the poet presents in these poems; it differentiates him from other writers who merely re-echo or document events. As a contemporary poet, he captures the significant events of our time in its ordinariness and he therefore agrees with Srdjan Smajic's (1) perspectives on realism which "exemplify a mode of perceiving, comprehending, and representing persons, objects, and events in accordance with natural laws and rationally explicable causal relations". Based on this materialist frame of reference presented in these selected poems from Gather My Blood Rivers of Song, Raji has demonstrated that he is an objective marker of contemporary issues as he resists the fantastic, extravagant and the whimsical narrations in his poetry but is able to actualize real events through a narrative model in which characters and settings are identifiably referenced.

\section{Works Cited}

Achebe, Chinua. Hopes and Impediments: Selected Essays 1965-87. New York: Anchor Books, 1990. . Things Fall Apart. Ibadan: Heinemann, 1958.

Edwards, Paul. The Encyclopedia of Philosophy. New York: Macmillan, 1967.

Egya, Sule. Poetics of Rage: A Reading of Remi Raji's Poetry. Ibadan: Kraft Books, 2011.

. The nationalist imagination in Remi Raji's Lovesong for my Wasteland." Research in African Literatures 38.4 (2007): 111-26.

Irele, Abiola. The African Imagination: Literature in Africa and the Black Diaspora. Oxford: OUP, 2001.

Jeyifo, Biodun. "'Umuofia' and 'Nwofia': Locality and universality in Things Fall Apart." Blazing the Path Fifty Years of Things Fall Apart. Eds. Chima Anyadike and Kehinde Ayoola, Ibadan: Heinemann, 2012. 1-27.

Lazarus, Neil. "Realism and naturalism in African Fiction." African Literature: An Anthology of Criticism and Theory. Eds. Tejumola Olaniyan and Ato Quayson. Malden MA: Blackwell, 2007. 340-3.

Lukács, George. The Meaning of Contemporary Realism. Trans. John and Necke Mander. London: Merlin, 1977.

Oha, Obododinma. "The rhetoric of cross-cultural engagement and the tropology of memory in Remi Raji's travel poetry." Iba: Essays on African Literature in Honour of Oyin Ogunba. Eds. Wole Ogundele and Gbemisola Adeoti. Ile-Ife: Obafemi Awolowo U P, 2003. 137-50. 
Morris, Pam. Realism: New Critical Idiom. New York: Routledge, 2003.

Olafioye, Tayo. The Poetry of Tanure Ojaide: A Critical Appraisal. Lagos: Malthouse, 2000.

Oripeloye, Henri. "Sociopolitical temper in Tayo Olafioye's The Parliament of Idiots and A Carnival of Looters." The Mines of His Mind: Critical Reflections on the Works of Tayo Olafioye. Eds. Beth Virtanen and Sola Owonibi. Trenton: Africa World Press, 2008. 13-28.

Raji, Remi. Gather My Blood Rivers of Song. Ibadan: Diktaris, 2009. . Webs of Remembrance. Ibadan: Kraftgriots, 2001.

Rosenblatt, Louise. Literature as Exploration. New York: The Modern Language Association of America, 1995.

Schnieder, Benjamin and Tatjana Soldkoff. "In defence of fictional realism." The Philosophical Quarterly 59:234 (2009): 138-49.

Smajic, Srdjan. "Supernatural Realism." Novel: A Forum on Fiction 42.1 (2009): 1-22.

Todd, Samuel. "Imaginability, morality, and fictional truth: Dissolving the puzzle of 'imaginative resistance."” Philos Stud. 143 (2009): 187-211.

Uwasomba, Chijioke. "Nigeria's new writing and the shrinking imaginative afflatus: Some theoretical and critical responses." The African Symposium: An Online Journal of the African Educational Research Network 13.1 (2013): 98-100.

Wellek, Rene and Warren Austin. Theory of Literature. New York: Penguin, 1978. 